DOI:

\title{
FINANCING INNOVATIONS IN THE CONTEMPORARY WORLD
}

\section{INTRODUCTION}

Although there is still no generally accepted definition of this term, many authors identify innovation with the emergence of new idea and their practical implementation to new products, services, and business processes, leading to the dynamic growth of the national economy and employment, as well as net profit for innovative enterprises (18, p. 3). Innovation is a multidimensional, complex, dynamic, long-term, and cumulative process consisting of many organizational and entrepreneurial decisions, from the emergence of a new idea to the phase of its final implementation. The new idea usually refers to the perception of new customers' needs, preferences, and tastes; new forms of business organization and conduction; a new way of service provision; a new way of marketing function realization in practice, etc. Innovation usually arises from entrepreneurial inspiration and vision and a comprehensive process of gathering information, leading to the development, application, and commercialization of a new marketable idea into a new product, service, or process, and increasing business efficiency and productivity.

The American Advisory Committee on Measuring Innovation defines innovation as the design, invention, development, and/or application of new or changed products, services, processes, systems, organizational structures or business models to create new value for consumers and generate returns for firms (14. p. xi). This definition recognizes the fact that innovation is not just a new idea and simple phe-

\section{SUMMARY}

Key words: financing innovations, economic growth, bootstrapping, crowdfunding, mezzanine financing.

As a practical application of new ideas, innovation is a multidimensional, complex, dynamic, long-term, and cumulative process based on organizational decision-making, from the stage of a new idea's emergence to its final implementation. There is a strong positive correlation between innovation and economic growth. Access to finance is a key driver of new innovative ventures' creation, survival, and growth. On the other hand, the lack of financial resources prevents and inhibits the growth and development of new innovative companies. This paper considers bootstrapping, crowdfunding, and mezzanine financing as widely accepted, specific innovation funding sources worldwide.

JEL Classification:

010, 030, 031, 036.

\footnotetext{
'Alfa BK University, Faculty of Finance, Banking and Auditing, Belgrade, e-mail: lidi.madzar@gmail.com

${ }^{2}$ This paper is part of the results within the research project II U-00I/20,"Assessment of the impact of Covid-I9 on social and economic development" of the Faculty of Finance, Banking and Auditing, Alpha BK University, Belgrade.
} 
nomenon, but that it carries an adding value component both for consumers and innovative companies themselves. Therefore, they are rightly considered as the driver of contemporary society's development and economic growth. There are three main approaches in the literature in assessing this concept (9, pp. 60-61): a) innovation as the consequence of the economy's impact on technological change and the use of a new combination of existing production factors (Schumpeter's view); b) innovation as a process that combines science, technology, economics and management intending to achieve and encourage novelty (Twiss's vision) and c) innovation as the inclusion of market, technological and administrative knowledge in creating new products, processes, and services (Afuaha's attitude).

\section{THE INNOVATIONS AND ECONOMIC GROWTH}

The vast majority of research indicates that there is a positive relationship between innovation and economic growth. Today, almost at the axiomatic level, the view is adopted that innovative activities are the only and most crucial component of longterm economic growth. Namely, increasing productivity and production of the economy can be achieved only in one of the following two ways $(12$, p. 1): a) by increasing the volume of factors that enter the production process and $b$ ) by introducing new, innovative ways to get higher output using the same level of inputs. In that sense, the importance of innovation directly contributes to productivity growth, and thus the economic and living standards increasing come to the fore. So, the development, introduction, and application of new ideas and technologies in practice create a higher output with the same level of inputs used (4).

For an economy to achieve its satisfactory growth level, it needs to be based not only on technology adaptions and imitations but also to develop and export state-of-the-art technology with the help of financing and other support for research and development (R\&D) and innovations. Suppose a country's shift to such a technological trajectory is successful. In that case, the development of innovations will require adequate market mechanisms, business environment, financing instruments, and government support to contribute to economic growth and development. Empirical evidence underscores that in this process, supporting R\&D activities plays a key role and the impact of the firms 'entry and exit from a market. Besides, the financing and development of financial instruments have a crucially strong influence on the innovative companies ' business. Therefore, in addition to the (in) quality of the institutional environ- 
ment and the level of market economy development, the lack of access to finance is cited as one of the main factors that directly inhibits innovative activities and entrepreneurship development in general (3, p. 80).

Dramatic moments from the history of industrial change have always been followed by the successful implementation of new, revolutionary ideas and innovative entrepreneurial achievements. Although the nature and landscape of innovation have changed over time, it is well known that the creation, use, and dissemination of knowledge play a fundamental role in the economic growth, development, and prosperity of modern nations. Through innovation, new knowledge is created and spread, while at the same time, the economy's potential for the development of new products and more productive business operations are expanded. Such improvements depend not only on technological knowledge but also on other forms of knowledge used for the development of production, process, marketing, and organizational innovations $(5, \mathrm{p} .1)$. Innovations in their significance go beyond the role of inventions because they represent the edge on which novelty is transformed into a concrete reality that brings benefits. Finally, competitiveness itself stems from the ability to create the differentiated and diverse capabilities needed for sustainable growth in a nationally and internationally competitive environment (1). While such skills are created by innovation, creative learning and dissemination of knowledge itself lead to the promotion and growth of modern enterprises and nations' productivity, efficiency, and competitiveness.

\section{FINANCING INNOVATIONS}

Access to finance is a key driver of the creation, survival, and growth of new innovative ventures. Lack of financial resources usually inhibits and distracts new companies from investing in innovative project ventures, improving their productivity and efficiency, from financing their growth needs, meeting their working capital needs, and thus from satisfying market demand. The empirical evidence testifies to the importance of access to finance as a key determinant of entrepreneurship and identifies the financial gap that exists for many new and especially small companies that are characterized by an early stage of innovation development. This is especially the case with innovative firms operating in high-risk capital markets (15). In this sense, the different types of funding sources' importance vary depending on the firms ' business and innovative project development phase. 
The disposition of financial resources has a crucial role in the development and implementation of innovations because it enables contemporary companies to conduct research, use the technology needed to develop them, and develop and commercialize their inventions and innovations. Therefore, access to external sources of innovation funding is a great challenge and often a problem for contemporary innovative companies. They can finance their innovative activities using various financing instruments provided by governments, financial institutions, and investors. Access to external sources of finance is especially a significant challenge in the initial and early stages of their business development. In this phase, innovative companies usually face major obstacles to obtain necessary funds because they still do not achieve significant and recognizable business results (17).

Due to all the described funding obstacles, during the early and initial phases of their business operations, innovative companies, whose growth is strongly driven by new technologies, can obtain entrepreneurial capital either from family members or friends, acquaintances and colleagues. In this stage of business, self-funding is of particular importance for these firms because innovative entrepreneurs cannot overcome the problem of information asymmetry and can rarely find lenders or investors, even for potentially profitable projects. Consequently, their initial capital funding can be compensated from informal private investors, such as business angels, seed funds, and venture capitalists (15). Small innovative companies often face information asymmetry problems, making it much more difficult for them to finance themselves through traditional financing sources such as bank loans. Asymmetry of information occurs when one of the parties in some economic transaction, and in this case in the financing of innovations, has more material knowledge and information than the other party, which can all affect the outcome of that transaction. As a consequence of information asymmetry, one party of the transaction may gain an advantage over the other. At the same time, this phenomenon may also lead to market failures, business imbalances, and even exploitation (11). In addition, funding of innovations can be burdened by a lack of trust, in the literature often referred to as Double Trust Dilemma. This problem, or rather the paradox, occurs in the interaction between the entrepreneur and investor when the entrepreneur strives to find external funding sources for his innovative venture. To convince the investor to provide him with the necessary funds, the entrepreneur needs to revile valuable information about his/her innovative idea. However, once that idea is discovered, there is a risk that the investor will steal or imitate the entrepreneur's idea $(7, \mathrm{p} .11)$.

In the later phases of innovation development, with the introduction of prototypes and the commercialization of inventions, 
specialized investors who evaluate innovation and new technologies and manage risks, such as venture capitalists and business angels, become all more willing to provide funding. In these stages, at the given level of adoption and dissemination of new technologies, after technological and market uncertainties almost disappear, more traditional financiers can provide the necessary funds to expand business operations and finance customers interested in using innovative products and services (17). Companies can use either internal (retained earnings, i.e., profit) or external funding sources for their innovative ventures. They usually prefer to use their internal funding source over external ones, as the latter can be very expansive and often unavailable. As a result, there are innovative projects that firms would be happy to embark on if they had sufficient internal funds but which won't be undertaken if external sources would be used. In many cases, external funding sources include borrowing and investors ' participation in the innovative company's capital, or some of their hybrid form, which, among other things, can be provided by individual investors, such as business angels, venture capital owners, banks and financial markets. In this sense, borrowing is usually more popular than other forms of financing because loans are typically available and represent a cheaper source of financing, even if it would still be more expansive than internal resources.

The literature on entrepreneurial finance explores various definitions and classifications of founding sources 'various types in innovative contemporary enterprises. In most cases, different types of funding sources are grouped based on investor participation in equity or borrowing. Still, there are also their classifications based on the financial characteristics of the entrepreneurial investor, investment objectives, and investment approaches. In addition to traditional public and private sources of financing innovations such as debt financing, i.e., borrowing, direct loan subsidies, loan guarantees, creation of public funds and "fund of funds," mutual funds, venture capital, public-private partnerships, public-public partnerships, various government incentives, business angels ' capital, tax incentives for investment in innovation, government subsidies, donations and grants, today there is a diverse network of very exotic and delicate instruments for financing innovations such as crowdfunding, mezzanine financing, mixed financing, syndicated loans, bootstrapping and Initial Coin Offering (ICO). These new sources of funding have opened new chapters in entrepreneurial finance $(13$, p. 138). Due to the limited scope of this paper, in its continuation, attention is paid to the most interesting of them, with which the domestic Serbian readership is probably not sufficiently familiar. 


\section{BOOTSTRAPPING}

New and young business companies face big problems, difficulties, and uncertainties at the beginning of their operations. And it is even more difficult for young enterprises that are engaged in the development of innovations since their business requires the support of external donors and financiers. In that sense, financing appears one of the main drivers of innovations in the current business market (10). Since the development and implementation of innovations require significant funds, the financing of innovations also affects those market actors who can embark on this venture. Entrepreneurs in the early stages of innovations' development largely depend on their internal funding because they have yet to build the necessary knowledge, skills, and experience. At the same time, they aim to reduce operating costs and improve their cash flow through advance payments from customers or by delaying payments to their suppliers, minimizing their investments or receivables $(13, \mathrm{p}$. 139). Experience shows that bootstrapping is a significant source of capital for newly established innovative business ventures. Its goal is to maintain the flexibility and independence of the innovative venture by reducing dependency on external funding.

Bootstrapping is a characteristic source of funding for startups and young companies that rely on money from entrepreneurs, members of his/her family, and a circle of his/her friends, acquaintances, and colleagues. In its narrowest sense, bootstrapping is defined as building a company from the ground up, from the personal savings of the entrepreneur (8). This term reminds of a synonym for something conducted and achieved with great effort and in aggravating circumstances. Translated into the language of innovations, the minimal and scarce resources available to the entrepreneur can prevent growth, inhibit progress, and even undermine the quality and integrity of an innovated product, process, or service. However, the advantage of this funding type is reflected in the fact that the entrepreneur remains able to maintain complete control over all decisions and its business operations. While all attention and energy go into the innovation process itself, innovations are not focused on attracting venture capital, business angels ' capital, and other potential sources of external investment. Bootstrapping is rarely a quick way to make a profit. Bat it can be a mode to slowly generate revenue and establish an adequate mechanism to fund future investments in innovative ventures. This form of financing allows entrepreneurs to experiment more with their innovation because there is no pressure from investors to achieve market success immediately. However, one of the disadvan- 
tages of bootstrapping may be the lack of credibility provided by the support of reputable investors.

\section{CROWDFUNDING}

Crowdfunding is also one of the newer sources of funding that can be defined as raising money most often through Internet platforms, and in rare cases, via SMS messages from many people. Typically, users of specific internet platforms set aside small amounts of money for crowdfunding purposes, which enables the realization of an innovation project or the launch of an innovative venture while providing young firms capital as an alternative to traditional sources of capital such as venture or bank capital, venture capital funds, financial market instruments, business angels, etc. In recent years, such funding from mass sources has begun to receive increased attention due to its general prevalence in creative, social, sports and art projects, all the way to the possibility of buying company shares (equity crowdfunding) or acquiring joint property (real estate crowdfunding) (13, p. 140). Crowdfunding allows innovators to test their innovative products, processes, services, or business ideas, build a network of their users, and promote their campaigns through social media. Usually, the funds allocated in this way imply obtaining monetary or non-monetary compensation. At the same time, the owner of the Internet platform acts as an intermediary and receives compensation for the performed transactions.

Like bootstrapping, crowdfunding is also present in the initial stages of financing innovative business ventures and does not require a relatively high level of financial market development. As a result, entrepreneurs have begun to rely more on this source of financing their innovative investments. Crowdfunding has many benefits. First, it can encourage and accelerate innovations by offering new sources of capital to innovative firms, thus reducing their funding gap. Second, this type of financing provides many people with the opportunity to participate in the innovation process by providing the necessary feedback information to the entrepreneur himself/herself. This feedback can take various forms, including giving ideas for innovative product development during and after the campaign and providing valuable information about future demand for new products, services, and processes $(7, \mathrm{p} .1)$. The development of this funding form was accelerated after the global financial and economic crisis of 2008, probably because the supply of traditional financial resources to small and medium-sized enterprises (SMEs) decreased significantly over time. Today, various forms 
of crowdfunding can be based on rewards, donations, loans, and capital financing. The apparent reason for the emergence of different types of crowdfunding is the occurrence of a wide range of innovative projects that can be funded in this way. A significant feature of crowdfunding is the fact that a group of people can be asked to evaluate an innovative project or at least provide feedback on an innovated product that is yet to be produced, with the mass of people (end-users of the innovated products and services) providing the funds, ideas and the necessary feedback to the innovator. Reward-based crowdfunding generally involves allocating smaller amounts of money; it is carried out by very small innovative firms. This type of funding typically carries with itself the non-financial motivation of backers. Crowdfunding based on loans, in which the amounts acquired are also often small, is now characterized by the financial reason of the backers, i.e., sponsors. Finally, there is capital crowdfunding, in which investor decisions are also guided by financial motivation (7. pp. 8-9). Capital crowdfunding typically involves more long-term investments, making it more likely to fund long-term and larger innovative projects.

\section{MEZZANINE FINANCING}

Unlike the previously mentioned sources of financing, mezzanine financing is usually present in the later stages of the development of an innovative project. It requires a relatively higher level of financial institutions' development. Mezzanine financing is a hybrid, i.e., a combination of debt and capital financing that gives the lender the right to convert its claim into a share in the capital of an innovative company in case of its default, but after the payment of venture capital or other senior creditors. This financing method is a specific way contemporary companies raise funds for certain innovative projects through hybrids of debt and capital financing. Mezzanine debt has built-in equity instruments, often known as warrants, that increase the value of subordinated debt and allow greater business flexibility. Mezzanine financing is often associated with acquisitions and buyouts. (6). In this case, this type of financing can be used to give priority to new owners over existing ones in the event of the bankruptcy of an innovative company.

Thus, mezzanine financing bridges the gap between debt financing and equity and, as such, represents one of the riskiest types of debt. The debt repayment priority is located somewhere between the older, i.e., higher net debt, and the classic net capital (preferred and ordinary shares). However, it also means that this type of financing brings some of the highest returns 
compared to other, more classical styles of debt. Mezzanine financing is often brought down to unsecured debts, while it is provided by long-term investors, as well as existing financiers, i.e., the founders of the innovative company's capital. Mezzanine financing is available to companies that have positive cash flows and that need additional financial resources for further growth through expansion, but sometimes also through management, purchase of a controlling stake, acquisition or initial public offering (13, p. 145). This form of funding, as a hybrid of debt and equity financing, gives the lender the right to purchase shares of a given innovative company (in the form of attached warrants or through ownership conversion). At the same time, the borrower has to pay interest (in the form of cash interest or payable in kind interest). However, when they use this type of financing, innovative companies could lose their business independence due to external capital representatives' possible influence and interference in their business decisions.

\section{CONCLUSIONS}

Innovations have become one of the most important strategic means for achieving and maintaining the competitive advantage of both contemporary companies and the countries themselves. The availability of resources for their financing is considered a key factor in the introduction, development, and further encouragement of innovations, while financial markets and financial institutions are also essential elements of national innovation ecosystems. Innovations directly stimulate economic growth because of the ability to create and commercialize innovative products, services, and processes that directly affect the realization and maintenance of competitive advantage. Today, innovative companies worldwide are becoming the most critical drivers of innovation, strengthening the innovative capacities of contemporary countries (2, pp. 93-94). At the same time, the innovative activities of modern companies are strongly supported by the dynamic presence of appropriate financial institutions, without which it would not be possible to imagine the development of innovative business ventures today. There is a strong interdependence between innovations, economic growth, and financial activities. At the same time, the level of development of available financial instruments plays a significant role in economic growth, especially in encouraging and developing innovations. Private capital companies, venture capital companies, commercial banks, business angels, but also a bunch of people, i.e., a crowd, friends, acquaintances, and colleagues, etc., are just some of the financial intermediaries that 
determine the pace of introduction and development of innovations today.

Access to financial resources is a key driver of the creation, survival, and growth of innovative enterprises. Lack of financial resources can prevent these companies from investing in innovative projects, improving their productivity and efficiency, financing their development, covering their working capital needs, and meeting market demand. Even if the innovation process may consist of the same stages in small and large multinational corporations, funding sources differ dramatically. Large companies can finance their innovative activities in a much easier way, either by using their internal financial resources, by taking loans from commercial banks, by issuing and selling bonds and shares, or by raising their funds in the financial markets. On the other hand, it is well known that young, and especially small innovative companies, do not have as many funds to use in the form of collateral, which is why their investments in innovation are less diversified.

In contrast, such investments can represent a much larger share in their business activities (16). As a result, their funding opportunities are more limited, and their owners often have to rely on friends, acquaintances, colleagues, and relatives before they can gain access to other sources of capital at all. They can achieve this aim through crowdfunding and bootstrapping as proven successful funding sources for innovation in the early stages of their business. In the later stages, more traditional financial instruments are available to them, such as various bank loans and mezzanine financing, which can finally increase their return on investments in innovative business ventures.

\section{REFERENCES}

1. Cantwell, J. (2009). Innovation and Competitiveness. The Oxford Handbook of Innovation. Jan Fagerberg and David C. Mowery (editors). Oxford University Press. Oxford. Available at: https://www.oxfordhandbooks.com/view/10.1093/oxfordhb/9780199286805.001.0001/oxfordhb9780199286805-e-20\#oxfordhb-9780199286805-div1-116, Accessed on: $06 / 18 / 2021$

2. Demirhan, D., Babacan, Ö. (2016). The Role of Financing in Innovation Ecosystems: A Panel Data Analysis. Ege Stratejik Araştirmalar Dergisi, 7(Özel):93, April 2016. pp. 93-104.

3. European Bank for Reconstruction and Development. (2012). Diversifying Russia: Harnessing regional diversity. December 13, 2012. EBRD. London.

4. European Central Bank. (2017). How does innovation lead to growth?. Available at: https://www.ecb.europa.eu/explainers/tell-me-more/html/ growth.en.html, Accessed on: 06/12/2021

5. Hadzimustafa, S., Rexhepi, G. (2011). Measuring innovation in the 21st Century Economy. SSRN Electronic Journal, September 2011, DOI: 10.2139/ssrn.1929039. Available at: https://www.researchgate.net/pu- 
blication/228166524_Measuring_Innovation_in_the_21st_Century_ Economy, Accessed on: 05/22/2021

6. Hayes, A. (2020). What Is Mezzanine Financing?. Investopedia. Jun 1, 2020. Available at: https://www.investopedia.com/terms/m/mezzaninefinancing.asp, Accessed on: 06/14/2021

7. Hervé, F., Schwienbacher, A. (2018). Crowdfunding and Innovation. Journal of Economic Surveys, 32(1). pp. 1-28. Available at: https:// www.researchgate.net/publication/326151352_Crowdfunding_ and_innovation Accessed on: 06/15/2021

8. Kenton, W. (2020). What is Bootstrapping?. Investopedia. September 20, 2020. Available at: https://www.investopedia.com/terms/b/bootstrap.asp, Accessed on: 06/14/2021

9. Kogabayev, T., Maziliauskas, A. (2017). The definition and classification of innovation. Holistica, Vol. 8, Issue 1. De Gruyter Open. pp. 59-72.

10. Leigh Hazzard, T. (2021). Bootstrapping Innovation: 6 Tactics That Work. Inc.com. Available at: https://www.inc.com/tracy-leigh-hazzard/bootstrapping-innovation-6-tactics-that-work.html, Accessed on: $06 / 14 / 2021$

11. MasterClass. (2020). Information Assymetry Explained (With Examples). MasterClass.com. Available at: https://www.masterclass.com/ articles/information-asymmetry-explained\#a-brief-history-of-information-asymmetry, Accessed on: 06/18/2021

12. Rosenberg, N. (2004). Innovation and Economic Growth. OECD. Available at: https://www.oecd.org/industry/tourism/34267902.pdf, Accessed on: 05/26/2021

13. Szulczevska-Remi, A. (2019). Financing Innovations. in Managing Economic Innovations - Ideas and Institutions. R. Romanovski (editor). Bogucki Wyd. Nauk., Poznań. pp. 137-152.

14. The Advisory Committee on Measuring Innovation in the 21st Century Economy. (2008). Innovation Measurement: Tracking the State of Innovation in the American Economy. January 2008. The Advisory Committee on Measuring Innovation in the 21st Century Economy. Washington DC.

15. The Innovation Policy Platform. (2013). Access to finance for innovative entrepreneurship. OECD and World Bank. Available at: https:// www.innovationpolicyplatform.org/www.innovationpolicyplatform. org/content/access-finance-innovative-entrepreneurship/index. html?topic-filters=12087, Accessed on: 06/12/2021

16. The Innovation Policy Platform. (2013). Demanding for financing innovation. OECD and World Bank. Available at: https://www.innovationpolicyplatform.org/www.innovationpolicyplatform.org/content/ demand-financing-innovation/index-2.html?topic-filters=8714, ACcessed on: 06/12/2021

17. The Innovation Policy Platform. (2013). Financing Innovation. OECD and World Bank. Available at: https://www.innovationpolicyplatform.org/www.innovationpolicyplatform.org/content/financing-innovation/index.html, Accessed on: 06/12/2021

18. Urabe, K., Child, J., Kagono, T. (1988). Innovation and Management: International Comparison. Walter de Gruyter. Berlin and New York.

\section{FINANSIRANJE INOVACIJA U SAVREMENOM SVETU REZIME}

Ključne reči: finansiranje inovacija, privredni rast, bootstrapping, crowdfunding, mezaninsko finansiranje.

Inovacije, kao praktična primena novih ideja, predstavljaju multidimenzionalni, složen, dinamički, dugoročni i kumulativan proces koji se zasniva na organizacionom odlučivanju, od faze nastanka nove ideje pa sve do njene konačne primene. Između inovacija i privrednog rasta postoji jaka pozitivna korelaciona veza. Pristup finansijskim sredstvima predstavlja ključni pokretač stvaranja, opstanka i rasta novih inovativnih poduhvata. Sa druge strane, nedostatak finansijskih resursa sprečava i sputava rast i razvoj novih inovativnih preduzeća. Ovaj rad razmatra bootstrapping, crowdfunding i mezaninsko finansiranje kao u svetu široko prihvaćene, specifične izvore finansiranja inovacija. 